\title{
The Hot one Hundred Choreographers: a tênue fronteira de memeplexos
}

The Hot one Hundred Choreographers: the tenuous frontier of memeplexes

Marcos Bragato $^{1}$ 


\section{Resumo}

A aptidão Memética de The Hot one Hundred Choreographers, de Cristian Duarte, encontra-se na postura da tênue fronteira entre o que se pode evocar e o que se pode acrescentar nas 100 unidades artísticas enformadas historicamente e constituintes de conjuntos de memeplexos, os conjuntos de unidades culturais, em dança. A aptidão memética de Hot100 reside na capacidade de realizar um jantar comensal de conjuntos meméticos "rivais" em uma dança-lista. Ela se dá semanticamente por meio de engenhosa replicação sintática, e informa que se pode superar a revisita. Retornar a essa maquinaria memética pertence a outro conjunto de memes: os da apropriação dos arquivos, os da ressignificação de conjuntos de memes em dança e o engendrar de novas instruções a partir de ideias comumente aceitas. Por isso, os memes mais comuns são comuns porque são bons replicadores, trabalham em vantagem própria e não do corpo que os expressam.

Palavras-chave: The Hot one Hundred Choreographers; teoria da memética; Cristian Duarte

\section{Abstract}

The Memetics fitness's of The Hot one Hundred Choreographers, by Cristian Duarte, is the posture of the fine line between what you can conjure and what you can add in 100 artistic and historically-formed units constituents memeplexes sets, sets of cultural units in dance. Hot100's memetic aptitude lies in the ability to hold a dinner of "rival" memeber sets in a dance-list. It occurs semantically through ingenious syntactic replication, and informs you that you can overcome the revisit. To return to this memetic machinery belongs to another set of memes: those of the appropriation of the archives, those of the re-signification of sets of memes in dance and the engendering of new instructions from commonly accepted ideas. Therefore, the most common memes are common because they are good replicators, they work at their own advantage and not the body that express them.

Keywords: The Hot one Hundred Choreographers; memetics theory; Cristian Duarte.

ISSN: 1414.5731

E-ISSN: 2358.6958

${ }^{1}$ Coordenador e Prof. Dr. Licenciatura em Dança - Departamento de Artes da Universidade Federal do Rio Grande do Norte (UFRN/RN). mabragato@hotmail.com 


\section{Memética I}

A Teoria da Memética é uma realidade epistêmica cujo lugar se inicia quando Richard Dawkins (2008) postula Outra Unidade Replicante não genética que se efetiva por imitação de ideias, conceitos e comportamentos, e que pode estar estendida nos objetos. Os memes não são entidades ou populações de informações sem lastro, ao contrário do que afirmam seus detratores. Os memes são pacotes de informações com "atitude" e se enformam por diferentes espécies, e podem florescer mesmo com impacto negativo na aptidão genética.

O modelo de análise da memética é propício à instalação da engenharia reversa no âmbito dos eventos da Cultura; que o diga o pesquisador e musicólogo britânico Steven Jan (2003). Como temos abordado (Bragato, 2009, 2011) com o material artístico encetado na piscina de memeplexos urdidos na produção do coreógrafo paulista Cristian Duarte, ele contém avenidas que podem contribuir à formação do entendimento dos infomemes em dança, que são replicáveis e transmissíveis e sujeitos tanto à inércia como à variação memética.

O entendimento solicita novo posicionamento sobre dança ser um fenômeno "efêmero", o que é flagrantemente contraditório e omisso dos atalhos moldados ao longo das gerações de produtores da materialidade artística em dança, expressos nos efeitos fenotípicos na forma de dançamemes inscritos na mente e, também, em dançamemes relatados em produtos extrassomáticos, artefatos de danças como as coreografias e nos arquivos que podem conferir outra materialidade memética. Portanto, o meme não é o dançarino. É a instrução ou a ideia cujo comportamento de dança se materializa (Gleick, 2011) para além do conceito que enforma qualquer tipo de dança; mas o meme pode também ser uma coreografia, ela mesma como uma entidade que ganha vida no mundo ao suscitar novas instruções comportamentais ou unidades culturais que são lembradas.

Nesse sentido, o meme é um replicador evolutivo que pode ser definido como uma informação copiada de pessoa a pessoa por imitação, sujeita ao processo de seleção natural, como ocorre nos eventos naturais. São tipos de ideias complexas que se agrupam em unidades presentes na memória de quaisquer hospedeiros de modos distintos.

O meme é a informação que faz com que uma dança seja aquela 'dança', e ela, por sua vez, é a expressão fenotípica do meme em qualquer meio físico, que, por sua vez, pode exibir também memes de outra ordem. O meme é um replicador cultural tal como uma tradição, crença, ideia, melodia, moda que pode ser copiado e expresso em fenótipos que, por sua vez, podem gerar outras instruções e ideias ali armazenados. A chave da memética é que memes podem diferir em seu grau de aptidão e adaptabilidade no ambiente sócio cultural no qual se propaga (Heylighen, 1998).

Por imitação, esta é a máxima vertida após Richard Dawkins nomear e cunhar o meme como um segundo replicador de natureza diferenciada do replicador genético, o primeiro replicador (Dawkins, 1998); e em imitação uma nova ação é aprendida pela cópia de uma outra depois de vê-la feita.

A imitação é um dos mecanismos de aprendizado diferente do simples contágio, do aprendizado individual e do aprendizado social não imitativo (Blackmore, 1999, 2015). A transmissão cultural se efetiva com a produção e percepção de estí- 
mulo na cadeia cotidiana de transmissão de informação acessíveis a nós (Claidiére, et al., 2014).

No entanto, estudos científicos têm reservado igualmente um importante papel da imitação em humanos e outros animais, especialmente quando grande parte do processo se efetive pela rede neuronal/mental inconsciente. Em humanos, por exemplo: nos processos de aquisição de itens como posturas corporais específicas de uma determinada cultura (Claidiére, et al., 2014). A imitação pode ser um mecanismo incrustado - wired - pela evolução, corroborado pela existência das células-espelho em nosso sistema nervoso central.

Como defende Dawkins (1998), toda a vida evolui pela sobrevivência diferencial de entidades replicantes, e, ao cunhar o meme, propõe o conceito de unidades culturais replicadoras cuja terra da desova é o cérebro. A cultura também evolui darwinianamente: variação (mutação), hereditariedade e aptidão diferencial à replicação.

Como a revolução darwiniana causa estragos à noção de um deus criador, a teoria da memética pode nos fazer refletir sobre nosso tradicional entendimento de responsabilidade, criatividade e intencionalidade. Nesse sentido, pode afirmar o filósofo Gustavo Leal-Toledo (2009, p. 427):

Tudo isso que gostávamos de chamar de nossa cultura, nossas ideias, nossas invenções, não é nossa, e sim fruto de um processo de evolução cultural onde a variação se dá ao acaso. O próprio sujeito não tem mais papel nenhum para representar, ele se tornou inútil. Darwin mostrou a inutilidade do sujeito universal e a memética poderá mostrar a inutilidade do sujeito individual. Por isso, o grande feito da memética pode ter sido destronar o sujeito assim como Darwin destronou deus.

O ácido universal (Dennett, 1998), atinge também a cultura humana, ela mesma um processo evolucionário que exibe mecanismos darwinianos chaves de variação, competição e herança (Mesoudi, et al., 2004). No entanto, da perspectiva universal darwiniana, evolução cultural não é análoga à evolução biológica (Dawkins, 1998), mas um paralelo equivalente membro de um conjunto de sistemas replicadores em operação na terra nos diversos meios, desde moléculas de DNA, caracteres alfabéticos, sons musicais e gestos, submetidos pela dimensão cósmica do Darwinismo Universal (Dawkins, 1998). O meme, ele mesmo, como um fragmento da cultura sob a égide do selecionismo opera também como um algoritmo darwiniano na esfera da informação cultural.

A aptidão Memética de The Hot one Hundred Choreographers (Hot100), de Cristian Duarte, com a colaboração de pesquisa e criação de Rodrigo Andreolli, encontra-se na postura da tênue fronteira entre o que se pode evocar e o que se pode acrescentar nas 100 unidades artísticas enformadas historicamente e constituintes de conjuntos de memeplexos, os conjuntos de unidades culturais, em dança; e a aptidão memética de Hot100 se encontra justamente na capacidade de realizar um jantar comensal de conjuntos meméticos "rivais" em cenário que se realiza especialmente por competição.

A dança-lista de Duarte replica semanticamente, por meio de engenhosa replicação sintática que, por sua vez, supera a posição dos que defendem a impossibilidade da reconstrução. 
Para a memética, é irrelevante o entendimento da dança como um construto sujeito ao desaparecimento, à efemeridade; como se as ideias e as instruções em dança por elas produzidas não replicassem de qualquer modo de modo direto por imitação e sujeitas aos mesmos mecanismos básicos de replicação, propagação, variação e seleção natural que fundamentam a evolução biológica.

A vaga recente por se debruçar sobre produções em dança ícones do século 20, como procedimento citatório e releituras, pode ser inserida em um conjunto de memes afetos principalmente à modernidade e pós-modernidade. Mas, esse memeplexo tem raízes históricas longínquas, como o debate impresso na produção intelectual medieval sobre o papel da cópia tão caro aos estudiosos dos monastérios do período.

A vontade de arquivo, como cunha André Lepecki $(2010,2013)$ sobre a recente vaga presente a partir dos anos 2000 na dança contemporânea, argui, no entanto, por uma ontologia pela efemeridade e precariedade da dança, e incorre em contradição quando se reconhece a existência do arquivo. Aceitar a existência do "arquivo" implica em aceitar a existência de "unidades".

Embora se possa arguir por tal efemeridade como uma estratégia estética na cena pós-anos-1960, a dança como um fenômeno fadado ao desaparecimento é ele mesmo um poderoso memeplexo, moldado por um conjunto de memes comandado pela ideia do evanescente, do fugaz, e do relativismo intrínseco à hermenêutica, cuja mensagem principal pressupõe a não-estandardização e, que o viés marxista denomina como ação contra a "fetichização" nas artes.

Ao recorrer à linhagem filosófica relativista de Michel Foucault (1926-1984) e Gilles Deleuze (1925-1995) e Jacques Derrida (1930-2004), Lepecki paralisa a sugestão da "vontade/desejo de arquivo" e a insere na análise típica dos filósofos pós-modernistas na qual a coerência parece escapar a olhos nus. Como quando afirma que o desejo de arquivo se encontra na capacidade de identificar nas obras campos criativos não esgotados de possibilidades impalpáveis (Lepecki, 2013). Ora, se elas são possibilidades elas podem ser de ambos modos, palpáveis ou impalpáveis, e continuarão a prescrever sua natureza: a da informação sobrevivente na infoesfera.

Embora Lepecki seja propositivo na defesa da vaga em determinado ambiente conformado por artistas americanos e europeus, ao tecer críticas do entendimento da causa dessa vontade de arquivo, circunscritas à epistemologia relativista com a qual disserta, a discussão gira em torno de questões que pressupõem a existência de um agente que faz a escolha deliberada por trazer à tona algo parte dos ícones e índices da história da dança. Desde já, são dezenas os exemplos de tentativas de retorno ao "arquivo" como fonte de aproximação ou distanciamento ao que está lá inscrito historicamente.

O meme como uma unidade da cultural, como entidade discreta, encontra-se nesse arquivo, cuja tarefa está facilitada por tratar as informações aos pacotes. No entanto, é forte a resistência em aceitar que trilhar esse caminho possa ser viável. Na opinião de críticos, "... é preciso estudar as partes a partir do todo e nunca o todo a partir das partes" (Leal-Toledo, 2009, p. 390).

É contraproducente a escolha porque implica em tarefa dada ao panorâmico, sem instrumental apto a especificar do que trata determinada questão. "A simplificação, a separação em partes, é uma estratégia para tratar a complexidade, e não uma 
negação dela" (Ibid., p. 391). Isso pode ser testado com a "engenharia reversa". Ela permite o fatiamento das partes para que possa administrar o todo com unidades analítica e conceitual.

A recombinação dessas unidades pode ser mais duradoura do que se imagina, ao contrário do que postula os fenomenólogos alinhados a escalas temporais não passíveis de observação na realidade disposta nos fatos. O quanto eles se aproximam ou se afastam estão encravados nas polaridades substanciadas em nossas mentes infestadas por memes. Por isso, adequa-se na perspectiva-do-meme quando essa vontade de arquivo é substituída pela nomeação do memeplexo "Do passado tudo se extrai", por exemplo.

A retórica sobre a memória proposta em análises de dança se revelam insuficientes para apontar a teia de dominância e submissão das informações e instruções presentes em quaisquer dos artefatos de dança, em ambientes de acirrada competição entre memes pela criação de padrões meméticos.

A "vontade de arquivo" pode receber outra explicação com a perspectiva do olho-do-meme: a evolução cultural se organiza no molde darwiniano lenta e inconsciente como um processo necessariamente que se esvai por muitas gerações sob o "gargalo do aprendiz": cada "aluno" é exposto somente a parte do conhecimento disponível na cultura na qual nasce e desenvolve (Merker, et al., 2016). Soma-se outra restrição: os limites de propagação de qualquer complexo memético que afetam sua transmissibilidade e sobrevivência na infoesfera, e não apenas na memoesfera.

As consequências podem ser visibilizadas no modo que o corpus cultural pode maximizar sua relevância, a economia expressiva, generalidade comunicativa e o poder "gramatical" para seu próprio benefício e não de seus hospedeiros.

Além de sua utilidade na explicação da dança como um fenômeno também formador de padrões - o memedança - e contra a visão corrente da dança como um produto efêmero ou um "processo em desintegração", a memética pode também oferecer convincentes explicações da expansão do cérebro humano, a evolução da linguagem humana, e em alguns casos a evolução da cultura animal (Blackmore, 1999).

A arte é uma massa de memeplexos como ciência e religião. Nessa massa, a dança tem sua parcela, e o produto que hoje denominamos como dança teatral molda-se como um grupo de memeplexos, como, por exemplo, quando aspira sua autonomia nas Cartas de Jean-Georges Noverre (1727-1810). A posição é crucial na massa geral dos memes que se espraiam historicamente.

Intentamos analisar a dança-lista de Hot100 com o entendimento de que a informação cultural evolui do mesmo modo que a informação genética. Para a Teoria da Memética, portanto, torna-se desprezível o entendimento de uma informação como sujeita ad aeternum ao desaparecimento, o que impossibilita sua replicação; como se as ideias e as instruções em dança por elas produzidas não replicassem de qualquer modo, de modo direto por imitação e indireto por variação: Ideias, melodias, instruções para artefatos, slogans, instruções para passos, artefatos e danças elas mesmas. Primeiro, apresentamos a perspectiva do olho-do-meme e segundo, abordamos a generalidade memética da dança-lista inscrita em Hot100. 


\section{Memética II: a perspectiva do olho-do-meme}

Na visão geral da memética, os memes mais comuns são comuns porque são bons replicadores. Isso significa que trabalham em vantagem própria e não em vantagem dos veículos que os portam. Na arguição de Dawkins, uma característica cultural poderá ter evoluído da maneira como o fez simplesmente porque é vantajoso para ela própria (2008, p.341).

Essa é a diferença da memética com outras teorias da evolução cultural: os elementos culturais, os memes, são replicadores ou entidades replicadoras e em especial em uma arena competitiva com outros memes. É uma teoria sobre a autonomia das coisas (Jouxtel, 2003) que competem por nossa atenção (Gleick, 2011).

Na perspectiva do olho-do-meme, os processos mentais são amplamente meme-dirigidos os quais com efeitos sobre nossa capacidade de conhecimento e na formação de nossos hábitos que são adquiridos pela exposição à informação de outros membros de nossa comunidade cultural ou da memosfera em ação (Jan, 2003). Não há agenciamento psicológico (Blackmore, 1999). São os próprios memes, e não as pessoas, os operadores do deslocamento para transpassar as barreiras de outros memes. Por isso, "[...] as diferenças de aptidões entre os memes podem se acumular, independentemente de qualquer avaliação ou cognição humana" (Dennett, 2006, p. 367).

Isso requer mudança no pensamento sobre o propósito último de nossas ações comumente racionalizadas em termos de metas ou crenças supostamente emanadas das "profundezas" de nosso aparato psicológico (Linquist, 2010) porque a envolvibilidade das populações de memes deve satisfazer as três condições para a seleção natural: hereditariedade, variação e aptidão diferencial (Dennett, 1995). A envolvibilidade carrega em suas fases a captura de instruções que são transmitidas de indivíduo a indivíduo, mas também desafiada pela possibilidade de informar por meio de artefatos as pequenas modificações a que estão sujeitas; no transcorrer das gerações é possível vizualizar a ação da seleção natural e seleção cultural (Linquist, 2010) no estado das características e a "incrível" (Blackmore, 2008, 2015) variação ocorrida que atesta a mudança evolutiva.

A explicação da mudança evolutiva pode encontrar elementos explanatórios em muitas de nossas ações assoalhadas por certas crenças e ideias particulares que resistem porque estamos sob o domínio de memes adaptados. Enquanto críticos a essa concepção consideram tal visão "desmoralizante", outros a defendem como astuta (Linquist, 2010). Da perspectiva de Richard Dawkins (2000) a explicação final para muitas de nossas ações é que elas são a maneira do meme de se replicar.

Como na biologia se escala o monte improvável pelos genes (Dawkins, 1998), na cultura a escalada do monte improvável se dá com os memes, entidades replicadoras informacionais que pulam de uma mente a outra e podem, também, fixarem em diversos tipos de materialidade produto de um cego algoritmo evolutivo, e sujeitos à variação/herança e seleção. Em dança, uma das mais poderosas são as ideias e as imagens das ideias em conjuntos de passos e movimentos que as informam na macroescala.

A teoria evolucionista na forma de um generalizado modelo darwiniano provê um mecanismo causal para explicar como a mudança ocorre na cultura humana. Um mecanismo simples, mas frutífero nas ocorrências das chamadas unidades culturais em seu ambiente em cooperação e concorrência com ambientes de unidades culturais diver- 
gentes: a mudança ocorre por meio da retenção seletiva da variação (Stuart-Fox, 1999). Isso leva ao entendimento de que a reprodução cultural, o componente genealógico, requer reiteração do comportamento de ideias selecionadas em ambiente competitivo por espaço em cérebros, e em artefatos como defendemos.

Quando Richard Dawkins introduz nos anos 1970 o conceito de meme inicia por outra via a discussão de se entender cultura com ferramentas que não as dos Culturalistas ao sugerir que a cultura evolui e nela os replicadores culturais são os memes. Eles são sujeitos à seleção do mesmo modo como os genes funcionam no mundo biológico. "[...] um fenômeno que obedece exatamente às leis da seleção natural" (Dennett, 1998, p.359) muda ao longo do tempo e evolui ao se transformar em ativo replicador. Nesse sentido, cultura é produto de um cego algoritmo evolutivo; uma receita com os passos necessários à realização de uma determinada tarefa, moldada no longo tempo da evolução humana. Esta é uma definição geral e não restrita ao mundo biológico.

Os memes são, portanto, unidades replicadoras da cultura transmitida por imitação; por exemplo, a capacidade de acionar um comportamento existente no repertório de outro indivíduo (Leal-Toledo, 2009). Um replicador é alguma coisa do qual cópias são feitas (Dawkins, 2004). Somos habilitados a copiar os outros em modos sofisticados não vislumbrado em outras espécies, o que nos tem conferido muitas das vantagens evolutivas. "Os memes não poderiam se espalhar, se não fosse o fato de os indivíduos terem a tendência biologicamente valiosa de imitar" (Dawkins, 2000). A capacidade tem como produto o capital da adaptação cultural cumulativa, quando aprendemos a moldar nosso ambiente pelo acúmulo de ideias face à nossa habilidade em se adaptar.

Nesse sentido, os memes evoluem do mesmo modo que os genes via seleção natural. Em consonância com o entendimento da mente como um lócus com capacidade limitada para abrigar memes (Dennett, 1995). Se não há lugar para todos alguns prevalecerão no ambiente da memosfera, similar ao que ocorre na biosfera na qual temos competição para a recepção e abrigo.

Os memes variam em consonância com as mutações na transmissão ou o armazenamento mental; eles replicam e desenvolvem aptidão diferenciada o que leva a fenômenos de concorrência, coevolução, dinâmica populacional e adaptação surpreendentemente semelhantes aos seus homólogos biológicos.

O conjunto de memes partilhados formam um memeplexo ou um pool de memes que podem funcionar como comensais, mutualistas ou competidores. Isso possibilita outro entendimento da cultura como uma competitiva e negociada arena de ideias e comportamentos. O conceito de unidades replicantes nos ajuda explicar por que uma ideia em particular se dissemina.

Para os memeticistas, o meme não é uma metáfora e nem uma ferramenta para a modelagem da evolução cultural, mas uma informação localizável em diversos sítios e, assim, a sua ontologia parece preservada.

Hoje, a discussão chave se centra sobre a precisão do local de seu armazenamento. Inicialmente, Dawkins (2008) sugere esse lugar apenas no cérebro. É no cérebro que se dá o armazenamento da informação, e se os memes residem no cérebro seus efeitos fenotípicos são suas consequências no mundo externo. A posição de 
Dawkins é revisada pelos memeticistas, e o estado da arte da discussão se centra entre a memética mentalista e a memética comportamentalista. Para a primeira, o locus do meme é o cérebro em acordo com a proposta original de Dawkins.

No entanto, o empreendimento memético de acordo com os comportamentalistas depende do mecanismo e do processo de transmissão mais do que seu conteúdo, ou seja, a discussão se torna sintática, em termos de organização das unidades culturais mais do que semântica. A abstração das estruturas em determinado artefatos pode ajudar ao entendimento dos aspectos sintáticos, do modo como se organiza.

Para os mentalistas, no entanto, o sucesso de um meme depende de sua semântica, o tipo de cadeia sígnica que se desenvolve. A crítica à posição mentalista é a de que não possibilita a existência de um observável. Mas isso não procede porque é possível acompanhar pelo método da engenharia reversa o movimento de um conjunto de memes ao longo do tempo.

A adoção de uma ou outra posição determinará o que se abordará em memética, se os sinais sintáticos ou os sinais semânticos. Em síntese: a posição que se adota resulta da definição de memes (Leal-Toledo, 2009) e do lugar que o encontramos. A definição da hospedagem dos memes passa a se constituir um importante problema ontológico para que se possa localizar como eles agem em nossas mentes por meio de um determinado comportamento como também nos produtos desse comportamento que, por sua vez, podem carregar padrões ou unidades que se "corromperam".

Por isso, como argumenta Kim Sterelny (2006), é frutífero olhar para a evolução cultural através do olho-do-meme: a atividade cultural humana como o efeito fenotípico de linhagem expandindo ao longo do tempo em aliança com algumas e em competição com outras.

Na perspectiva do olho-do-meme, as forças endógenas são os modos em como os memeplexos perduram e se espalham pela cultura humana e, em outra instância, entre partícipes da produção artística em dança, em nosso caso o da dança para a cena; as forças exógenas são os modos em como esses memeplexos se expressam na panóplia da memosfera em se distinguir da "vida comum".

\section{Mentalistas e comportamentalistas não são se sentam à mesa}

Os efeitos fenotípicos se realizam na forma de melodias, palavras, estilos de roupas, gestos manuais ou faciais, em danças de toda a sorte, e habilidades em geral. Ao serem percebidos, imprimem-se no cérebro dos indivíduos e não necessariamente como uma cópia do meme original. A cópia nova do meme, por sua vez, desencadeia outros efeitos fenotípicos como forma de criar mais cópia de si mesmo, e assim sucessivamente. No entanto, deve-se ressaltar que a capacidade adaptativa depende da frequência de replicação.

Todos têm a propriedade comum de possuir expressão fenotípica. Ela tende a maximizar a possibilidade de sua própria replicação ou ao serem açodadas pelas forças do entorno tendem a cavar sua própria extinção (Dennett, 1995). Graças aos efeitos fenotípicos tendem a desativar as forças seletivas contra eles ou não (lbid.).

Daniel C. Dennett $(1995,1998)$ soluciona o impasse quando opta pelo entendimento da continuidade entre os tipos de instanciação física, ainda que os memes tomem seu rumo a partir de nossas mentes. Como defende, não há descontinuidade radical: "pode-se ser mamífero, pai, estudioso, democrata e professor adjunto com detenção de cargo" 
(1998, p.382). A vasta rede de instanciação protetoras dos memes, como quer Dennett, são parte de nossos fenótipos.

Afinal, é a informação quem determina a quantidade de trabalho e por isso podemos tomar abstratamente a definição dos memes porque a incidência é sobre qual informação vale a pena copiar (Dennett, 2005). Como Daniel C. Dennett (Ibid.) justifica no caso de uma carroça com rodas raiadas carrega a própria ideia de uma carroça com rodas raiadas ou um cérebro pode também carregá-la. "Memes, como os genes, são potencialmente imortais, mas, também como os genes, dependem da existência de uma cadeia contínua de veículos físicos, persistindo a despeito da segunda lei da termodinâmica" (Dennett, 1998, p. 363).

Desse modo, o debate entre os memeticistas sobre qual o lugar por excelência dos memes, entre estruturas cerebrais ou comportamentos/artefatos, parece se dissolver porque eles são replicadores que se assemelham mais aos seus ancestrais imediatos do que ao restante da população (Dawkins, 1998,p. 103).

Adota-se a posição mentalista quando os memes podem ser estudados semanticamente. Adota-se a posição comportamentalista quando os memes podem ser estudados sintaticamente. Sabemos, portanto, que a "transmissão e armazenamento dos memes pode continuar indefinidamente em formas não-cerebrais - em todos os tipos de artefatos" (Dennett, 1998, p. 369).

Os substratos físicos de quaisquer mídias - cérebros, danças, e assim por diante - de replicadores são diversos nos modos de padrões tangíveis e visíveis no comportamento dos organismos vetores, de acordo com Daniel C. Dennett (2002). No entanto, comportamentos produzem artefatos tais como sinais e símbolos, ferramentas e abrigos (Dennett, 2002) que parecem se constituir em exemplares típicos de replicação do que os comportamentos que os produzem porque carregam maior estabilidade e de algum modo são mais fáceis de serem copiados como, também, independentemente móveis e armazenáveis (Ibid.). No entanto, podem sofrer ligeiras modificações na estrutura que são retidos e sobressaírem em grandes escalas de tempo.

Richard Dawkins (2001), posteriormente ao propor o meme, parece atentado à distinção quando afirma que os "novos replicadores" são padrões de informação "que podem desenvolver-se apenas em cérebros ou em produtos que os cérebros confeccionam artificialmente - livros, computadores etc." (Ibid, p. 235). Dawkins formula como central o ambiente da evolução cultural que nela obrigatoriamente alguma coisa se origina do processo anterior de seleção cumulativa (Ibid, p. 236).

Os substratos outros que não os genéticos também são substratos evolutivos satisfeitas as condições de replicação, variação (mutação) e aptidão diferencial (competição). Como Daniel C. Dennett $(1995,2006)$ argui, a natureza algorítmica da teoria da evolução por seleção natural implica (a) na existência de uma continuidade abundante de elementos diferentes - variação - (b) na replicação ou hereditariedade de elementos com capacidade de criar réplicas deles mesmos e (c) na variedade do número de cópias de um elemento que é criado em um dado período, a depender da intersecção entre os traços de tais elementos e traços do ambiente no qual eles se inserem, a aptidão diferencial.

Como as palavras, e as línguas que as povoam, são variantes transmitidas culturalmente como pacotes de informações, os memes. Em tais pacotes, que se espalham por imitação, atuam replicadores potencialmente ativos para gerarem o meio físico que os veicula. Como as palavras e as línguas, atos, ações e práticas humanas são mídias pelos quais a máquina memética se propaga. 
Portanto, e a partir do que propõe Steven Jan (2004), apresentamos um primeiro diagrama do entendimento em como o meme pode se deslocar pela memosfera:

\section{Geno/memotype (memotipos) - Pheno/phemotype (femotipos) encarnação mental do meme - resultante manifestação física operadores mentais - efeitos extrassomáticos}

Propomos um segundo diagrama como solução provisória: Geno/memotype - Pheno/phemotype - Geno/memotype encarnação mental do meme - resultante manifestação física - encarnação memética

operadores mentais - efeitos extrassomáticos - operadores meméticos

Conceitos, ideias, instruções - comportamento, artefato, produto artístico - Conceitos, ideias, instruções dispostos no ambiente extrassomático

Arguimos aqui, em acordo com o diagrama, a definição de replicação de Robert Aunger (2006) para quem é um caso especial de relação da fonte com a cópia se observadas quatro condições: causação - a fonte precisa oferecer as condições pelas quais pode oferecer possibilidade de efetivar a cópia - similaridade - fonte e cópia devem partilhar os elementos mais importantes - transferência de informação - o que torna a fonte semelhante com a cópia dever ser derivado da fonte - duplicação - fonte e cópia devem coexistir durante um período.

Por isso, os mutantes se transformam em uma unidade justamente porque percebemos suas variações e a células coreográficas que as desencadeiam. Embora se possa arguir por "infinidades" em quaisquer dos fenômenos relacionados à produção artística, e, em especial no tipo de conformação proporcionada pela dança cênica, o padrão se forma porque há limitações de natureza cognitiva; do contrário, não poderemos encontrar a sintonia fina obrigatória para entendermos o peso de cada elemento moldador das tais variações porque está na medida da capacidade de sobrevivência o sucesso de qualquer replicador.

\section{Interlúdio}

O certo grau de infidelidade é a cota desafiadora da noção Stricto sensu de plágio ou, como muitos autores confundem, como mimetismo. As formas de contágio estão enervadas em nós por meio das células-espelho moduladoras da rede dos chamados neurônios-espelho, as quais estão envolvidas na imitação. O mimetismo pressupõe o ato deliberado e avaliativo do agente; no modelo de imitação com o neurônios-espelho quaisquer comportamentos podem ser modulados sem a deliberação do agente.

O que se realiza é prospectar um possível cenário de instruções desenvolvidas em cada uma das peças e projetá-las sobre modos tangíveis de entendimento a si próprios. Isso elimina qualquer acusação de plágio. A história da dança clássica é recheada de exemplos, e não somente agora como se alega. A diferença fundamental da configuração de um memeplexo se encontra justamente no tipo de material memético que se encontra imerso.

A retórica da memória proposta em análises de dança se revelam insuficientes 
para apontar a teia de dominância e submissão das instruções presentes em quaisquer das instruções e artefatos de dança. Por isso, fazer uso da engenharia reversa parece solucionar o caso. Perscrutar as partes garante o entendimento da postura do design (Dennett, 1995) para se chegar à postura do comportamento. Dependemos do pedaço da realidade a ser fatiado, e esse pedaço pode conter instâncias aparentemente incompatíveis, mas que podem ser escrutinadas; e em muitas dessas instâncias a memética é operadora fundamental livre da psicologia humana. Contra céticos sobre o escopo teórico da teoria memética, ela se ancora na realidade de fatos os fatos concernentes ao primado de uma de nossas especialidades, a imitação.

\section{Hot100 e a Dança-Lista}

Um dos princípios fundamentais do universo darwiniano é que complexas estruturas podem somente florescer de conjunto de unidades simples para grande estabilidade e utilidade. E aqui se inicia uma corrida armamentista quando a partir de fontes "arquivais" se pode gerar outras configurações, as quais apenas algumas delas, por sua vez, tornar-se-ão fontes outras "arquivais".

A "vontade de arquivo" não se trata de agenciamento e tomada de decisão, como querem os autores vinculados aos vieses filosóficos pós-modernistas. Ela diz respeito à generatividade (Merker, et al., 2015): produz variedade infinita pelo padrão de meios finitos. A dança é organizada da padronização de parâmetros rítmicos na confluência entre temporalidade e espacialidade, embora se possa arguir pela prevalência da discussão entre os meios sintáticos e semânticos. No primeiro, parece prevalecer o memeplexo embebido pelo lema da "invenção" vocabular e dos arranjos possíveis sobre os elementos a serem organizados e o que se pode "inventar". No segundo, parece prevalecer o memeplexo embebido pelo lema "relatos das indiossincrasias da psique".

\section{Dança Não é Artefato Evanescente}

A dança-lista de Hot100 é crucial como prova da impossibilidade da evanescência postulada pela hermenêutica, embora possa haver vieses em ação a postular tal concepção não meramente como ferramenta metodológica, mas como uma ontologia. Não importa! Como ferramenta metodológica, apenas, podemos vislumbrar o rico cenário que se molda a partir dos 1990 no continente europeu, inspirado pelas experiências de artistas estadunidenses entre os anos 1960 e 1970.

Como se anuncia, Hot100 parte do texto-painting The Hot One Hundred do artista britânico Peter Davies e toma como assunto e material coreográfico 100 obras/coreógrafos com "manipulação, apropriação, mixagem dos conteúdos listados e, através da série de et ceteras, transitam por um turbilhão de referências fragmentadas que vão de Laban a Michael Jackson" (Duarte, 2011).

Nesse sentido, as mutações que levam a tais padrões são produtos de memes mutantes que possuem saliência cultural e que, por sua vez, são competentes para o incremento de sua herdabilidade e de sua representação estatística em meio a memes rivais. E sobre as coisas afetadas pelo meme mutante visibilizado na dança que 
evoluiu porque são as expostas à riqueza e diversidade do pool memético. Isso pode ser visibilizado na incessante mixagem de Hot100.

No entanto, deve-se lembrar que a variedade existe porque há coisas finitas, replicadores que ganharam estabilidade na competitiva memosfera. Justamente contrário à ideia de impermanência defendida pela hermenêutica que embebe as análises atuais sobre a produção artística da dança cênica, justamente como os produtos meméticos da corrida armamentista entre os balés de repertório do século 19 cuja Unidade se centra no "Mantenha-me Ativo" contra a Unidade do modernismo histórico centrada no "Faça-se o Novo" (vernáculo).

Hot100 nos oportuniza analisar com a ferramenta memética a organização sincrônica e a mudança diacrônica dos modos de tratar a cena em dança e a percussão de suas imagens que se transformam elas mesmas em poderosos memeplexos.

A existência do arquivo é produto da tendência de memes aglomerados em certos limitados modos que conduzem à formação de um relativamente pequeno de configurações - ênfases na verticalidade ou na horizontalidade - gestos constritores ou gestos expansivos, entre outras configurações básicas. Como elas se agrupam ou se organizam nos dão a dimensão por qual via elas modelam os conjuntos meméticos, como o gesto de levar a mão à boca aberta em clássica expressão do horror/espanto, que parece ter saído da imagem icônica da expressionista tela O Grito (1983) de Edvard Munch (1863-1944), e as enfáticas braçadas no ar, por exemplo. Ao se converterem em memes, transcendem o hospedeiro pelo qual eles sobrevivem e desafiam a inten(s)ionalidade.

A discretização da arte pode encontrar respaldo na observação de determinada unidade cultural memorável em como se replica o gesto de empunhar a mão na boca aberta "dramaticamente"; de modo enfático é um meme porque se pode vislumbrar replicado em muitos dos vieses herdeiros do expressionismo por sozinho ter prosperado. Mas em alguns casos prospera unido a uma massa de memes que podem ensaiar sua "libertação" desse viés expressionista.

Se a cultura fosse um todo indissociável ela só poderia ser aprendida como tal, ou seja, toda de uma vez só. No entanto, a cultura deve ser aprendida aos poucos ou não será aprendida. Por mais holística que ela seja, ela é aprendida em partes e, na verdade, ninguém nunca conhece todas as suas partes. O tempo que gastamos aprendendo uma parte é um tempo que não gastamos aprendendo qualquer outra parte de cultura. Como certas partes terão maior probabilidade de serem aprendidas do que outras, temos os ingredientes necessários para uma evolução darwinista esperada pela memética (Leal-Toledo, 2009, p. 243).

A sequência de memes, presentes em memeplexos, e em alelos meméticos, configuram a evolução das ideias e suas conexões com os comportamentos que os quais motiva sua existência. No entanto, memes e memeplexos podem se replicarem intactos em contexto diferenciado. Mas a história está repleta de exemplos de alelos meméticos: a imagem-padrão encarnada na dança de Mary Wigman (1886-1973), o nível $A$, pode se arguida a ter correspondência em nível $B$ com os alelos meméticos da dança butô.

Hot100 é darwiniano e não lamarckiano. Com as imagens da dança-lista, ela mesma testemunho da aptidão diferencial no cenário da memosfera, produto da com- 
petição em ocupar nossas mentes com instruções em dança, floresce um outro memeplexo por meio das regras e instruções de organização do vocabulário e do teor semântico nelas presente. Por isso, vale lembrar que replicadores meméticos têm sua sobrevivência por meio de veículos de fenótipos comunais que eles engendram.

A aptidão memética em Hot100, primeiramente em sua dança-lista, é semântica, embora parte da tarefa pode possa apontar particularidade justamente em como cada uma das danças se organiza e, simultaneamente, como o produto disso se organiza no corpo de Cristian Duarte. Por isso, adotar a posição dennettiana pode solucionar provisoriamente a discussão do loci dos memes em Hot100.

O caldo de hot100 funciona por um processo simbiótico, e às vezes mutualista. Dois portentosos memeplexos carreiam desde à difusão do Impressionismo nas artes visuais ideias e comportamentos fincados em dois vieses: O Que se Diz e Como se Diz. Transpõe fronteiras geográficas e desenvolvem um novo Ato na Memosfera.

Há uma tensão contínua entre unidades culturais de memeplexos de dança "rivais", o que reproduz em microescala o estresse que embebeda a competição entre traços de emoções negativas e positivas. Isso pode ser vislumbrado quando HOT100 se encerra com a unidade de Vestígios de Marta Soares potencialmente a sugerir o "encapsular" em confronto com o próprio propósito gerado pela obra, ao sugerir o "expandir"; a observação atenta poderá vislumbrar os efeitos fenotípicos no modo de se posicionar na cena, na organização de quais elementos gestuais e em sua visualização semântica.

Isso vale para a macroescala da produção cênica de Cristian Duarte na chave de sua aptidão memética: a capacidade de gerar outro memplexo quando insere o observador em jantar comensal, o de sugerir a possibilidade de convivência de entendimentos extremos de ritmo, passo, duração, sintaxe, semântica, e da utilização do grau de intensidade no desenho de movimentos e na geometria corporal formada por células de danças.

Tais células de dança e células coreográficas de conjuntos de memeplexos são as inscrições presentes nos conjuntos de entendimentos em como o corpo pode enformar simetrias e produzir assimetrias (Marius Petipa - 1818-1910), enformar assimetrias e produzir simetrias (William Forsythe), combinar uma sopa de expressões emocionais básicas fácio-corporais (Mary Wigman, Tatsumi Hijikata - 1928-1986, Pina Bausch - 1940-2009) ou rejeitá-las e se concentrar em como o vocábulo deve predominar (Merce Cunningham, Yvonne Rainer, Steve Paxton, Trisha Brown) e outros arranjos na memosfera (Gene Kelly - 1912-1996, Bob Fosse - 1927-1987, Michael Jackson - 19582009); Variação, Seleção e Hereditariedade operam nesse pool memético.

São inscrições também presentes em preocupações sintáticas: os elementos cinéticos, a sua organização em cada um dos memeplexos e como chegam à determinada organização como a prevalência da aproximação ou distanciamento dos corpos, a prevalência de movimentos retilíneos ou angulosos, bem como as consequências dessa organização nas formas híbridas hoje existentes na produção em dança contemporânea.

Hot100 parece tornar unidades culturais memoráveis em jogo simbiótico: coisas comuns em coisas "não familiares" e coisas "não familiares" em coisas comuns. Esse parece ser o elemento operador de sua aptidão memética. 
Por isso, retomar a essa maquinaria memética pertence a outro conjunto de memes: os da apropriação dos arquivos, os da ressignificação de conjuntos de memes em dança, o engendrar de novas instruções a partir de ideias comumente aceitas, e assim por diante. Na perspectiva do meme, os memes mais comuns são comuns porque são bons replicadores, trabalham em vantagem própria e não do corpo que os expressam.

Esse pool de memes do "Passado Tudo se Extrai" pode ter sido potencializado pela multiplicidade de máquinas, e não apenas pela maquinaria cerebral embora o "arquivo" retido em nossas mentes é quem encadeia o deslocamento de um meme ou de um memeplexo que parece estar "adormecido" em quaisquer dos artefatos. E isso "depende das forças seletivas que agem diretamente sobre os veículos físicos que os materializam" (Dennett, 1998, p. 362) a depender da manutenção, da persistência e da multiplicação de cópias (Ibid.) dos memedanças.

Esse pool de memes é produto da possibilidade de acumulação da informação cultural e, em nosso caso, transmitida via imitação. O produto disso é o "efeito catraca" (Tomasello, et al., 2009), no qual mutações/modificações permanecem ao longo do tempo em determinado grupo, com baixa perda, até que novas mudanças alterem o curso da evolução cultural. Isso impõe um desafio: práticas humanas e seus produtos somente podem evoluir se modificações incorporadas não se degradarem além do reconhecimento da fonte do processo e da instrução que carregam a unidade memorável durante sucessivas gerações.

\section{Consideração Finais}

Como no Rio que corre do Éden (Dawkins, 1996) de substâncias químicas, no rio que corre na memosfera de ideias, crenças, comportamentos, em sua extensão, fenótipos carregam os memes partilhados produtos da competição por conjuntos de memeplexos que lutam para se fixar em uma mente e se eternizarem em um artefato.

[...] é possível que a cultura humana tenha criado uma bomba de replicação genuinamente nova, com um novo tipo de entidade auto-replicante - o meme [...] proliferando e 'darwinizando-se' em um rio de cultura. (Dawkins, 1996, p. 136)

A dança-lista de Duarte não é apenas a oportunidade mantida pelo caldo de ideias em imagens de dança, mas também o conteúdo de forças exógenas escorreitas por diversas gerações de artistas. Os memes como populações darwinianas pulam de mente a mente a gerarem diversidade pelo processo de seleção, guardados os limites dessa diversidade face ao "gargalo" e ao efeito-catraca do processo acumulativo da cultura.

Hot100 nos oferece sinais corpóreos-conceituais de complexos meméticos dispostos no cabedal de muitas listas e a vaga dos anos 2000 é ela mesma um memeplexo disposto na esfera da produção cênica em dança. Esta, por sua vez, aponta para o fato de que a mente humana "não está limitada ao cérebro" (Dennett, 1997, p. 131). “Mantemos 'ponteiros' e 'índices' em nossos cérebros e deixamos a maior quantidade possível de dados reais que podemos no mundo externo, nas nossas cadernetas de endereços, bibliotecas" (/bid. id.) e em coreografias, encenações, em danças, "e, de fato, no círculo de amigos e associados" (Ibid. id.) 
O poderoso desafio é o de encontrar em qual lugar da geografia evolutiva cultural jaz o padrão do memedança, qual a ritmicidade da evolução, a que taxa podem aparecer novas propriedades estruturais e seus rumos que escapem de sua fonte, a ideia geradora expressa em comportamento de dança e que, por sua vez, ao conferir materialidade com artefatos pode gerar nova fonte. A tarefa se encontra avançada no estudo das árvores da linguagem humana (Pagel, 2009), mas inexiste entre nós, nos estudos sobre dança e sobre a dança para a cena.

\section{Referências}

AUNGER, Robert. What's the Matter with Memes? In: GRAFEN, Alan; RIDLEY, Richard Dawkins: How a Scientist Changed the Way We Think. Oxford: Oxford University Press, 2006

BRAGATO, Marcos. Bípede sem Pelo: O Caso das Emoções. Cadernos do LINCC: Linguagens da Cena Contemporânea, v. 2n. 3. Jul/dez. Natal: Programa de Pós-Graduação em Artes Cênicas, Universidade Federal do Rio Grande do Norte, 2009.

UMA TEORIA EM AÇÃO: os operadores na piscina memética de O Revisor em Série e Cornélia Boom. In: TRALL, Karin; RENGEL, Lenira. Corpo em cena. São Paulo: Anadarco, 2011.

BLACKMORE, Susan. Imitation and the Definition of a Meme. Journal of Memetics Evolutionary Models of Information Transmission, 2 (2), 1998. Disponível originalmente em: http:/ /cfpm.org/jom-emit/1998/vol2. Acesso em: 15 mar. 2016.

The Meme Machine. Oxford : Oxford University Press, 1999.

Memes shape brains shape memes. Commentary on Christiansen and Chater. Behavioral and Brain Sciences, 31(5): 513 - November 2008. Disponível em: http://www.susanblackmore.co.uk/Articles/PDFs/Memes\%20shape\%20 brains\%20shape\%20memes.pdf . Acesso em: 10 jul. 2016

Memes and the evolution of religion: We need memetics too. Commentary on Norenzayan et al.The cultural evolution of prosocial religions. Behavioral and Brain Sciences, 39, 22-3, janeiro, 2015.

CLAIDIÉRE, Nicolas; SCOTT-PHILLIPS, Thomas C.; SPERBER, Dan. How Darwinian is cultural evolution? Phil. Trans. R. Soc. B 369, 31 de Março 2014 Disponível em: http://rstb.royalsocietypublishing.org/content/369/1642/20130368 Acesso em: 17 jul. 2016.

DAWKINS, Richard. O Rio que Saía do Éden: Uma visão darwiniana da vida. Tradução de Alexandre Tort. Rio de Janeiro: Rocco, 1996.

A Escalada do Monte Improvável: Uma defesa da teoria da evolução. Tradução de Suzana Sturlini Couto. São Paulo: Companhia Das Letras, 1998. 
Desvendando o Arco-Íris: Ciência, Ilusão e Encantamento. Tradução de Rosaura Eichenberg. São Paulo: Companhia Das Letras, 2000.

O Relojoeiro Cego: A Teoria da Evolução contra o Desígnio

Divino. Tradução de Laura Teixeira Motta. São Paulo: Companhia Das Letras, 2001.

An ecology of replicators. Ludus Vitalis (Revista de la Ludus

Vitalis - Revista de la Filosofia de las Ciencias de la Vida, 12, número 21, p. 35-41, 2004.

O Gene Egoísta. Tradução de Rejane Rubino. São Paulo: Companhia

Das Letras, 2008.

DENNETT, Daniel C. La Conciencia Explicada: Uma Teoria Interdisciplinar. Barcelona:

Paidós Ibérica, 1995.

Tipos de Mentes: Rumo a uma Compreensão da Consciência.

Tradução de Alexandre Tort. Rio de Janeiro: Rocco, 1997.

A Perigosa Idéia de Darwin. Tradução de Talita M. Rodrigues.

Rio de Janeiro: Rocco, 1998.

The New Replicators. In: PAGE, Mark (ed.), The Encyclopedia

of Evolution, Vol. 1. Oxford: Oxford University Press, 2002.

Quebrando o Encanto: A religião como fenômeno natural.

Tradução de Helena Londres. São Paulo: Editora Globo, 2006.

DUARTE, Cristian. The Hot one Hundred Choeographers, 2011. Disponível em: http:// www.cristianduarte.net/available-works/the-hot-one-hundred-choreographers/ Acesso em: 10 Jun. 2016.

GLEICK, James. What Defines a Meme? Smithsonian magazine, Mai. 2011. Disponível em: :http://www.smithsonianmag.com/arts-culture/What-Defines-a-Meme.html\#ixzz23fSS2zT8 Acesso em: 20 jan. 2017.

HEYLIGHEN, Francis; CHIELENS. Cultural Evolution and Memetics. In: MEYERS, Robert A., Encyclopedia of Complexity and System Science, p. 190, 2009.

JAN, Steve. Meme Hunting with the Humdrum Toolkit: Principles, Problems, and Prospects. Computer Music Journal, 28:4, pp. 68-84, Winter, Massachusetts Institute of Technolog, 2004.

. The Evolution of a 'Memeplex' in Late Mozart: Replicated Structures in Pamina's 'Ach ich fühl's'. Journal of the Royal Musical Association, Vol. 128, No. 2, p. 330-370, 2003. 
JOUXTEL, Paul. Automates-Intelligents (Al). Disponível em: http://www.automatesintelligents.com/interviews/2003/janv/jouxtel.html Acesso em: 10 Jan. 2017.

LEAL-TOLEDO, Gustavo. Controvérsias Meméticas: a ciência dos memes e o darwinismo universal em Dawkins, Dennett e Blackmore. Rio de Janeiro, 2009. Tese (Doutorado) -Programa de Pós-Graduação em Filosofia do Departamento de Filosofia do Centro de Teologia e Ciências Humanas, Pontifícia Universidade Católica - Rio de Janeiro.

LEPECKI, André. El Cuerpo como Archivo: El Deseo de Recreación y las Supervivencias de las Danzas. In: NAVERÁN, Isabel de; ÉCIJA, Amparo (Org.) Lecturas sobre Danzas y Coreografía. Madrid: Artea Editorial, p. 59-81, 2013.

The Body as Archive: Will to Re-Enact and the Afterlives of Dances. Dance Research Journal, Volume 42, Issue 02, Dezembro, p. 28-48 2010.

LINQUIST Stefan. The Evolution of Culture: Volume IV. The International Library of Essays on Evolutionary Thought Series. Surrey: Neil Levy Ashgate Publishing, 2010.

MESOUDI, Alex; WHITEN, Andrew; KEVIN N. LALAND, Kevin N. Perspective: Is Human Cultural Evolution Darwinian? Evidence Reviewed from the Perspective of the Origin of Species. Evolution, 58(1), p. 1-11, 2004.

MACNAMARA, Adam. Can we measure memes? Frontiers in Evolutionary Neuroscience, May 2011, V. 3, Article 1 www.frontiersin.org Acesso em: 08 dez. 2016.

MERKER, Bjorn; MORLEY, lain; ZUIDEMA, Willem. Five fundamental constraints on theories of the origins of music. Phil.Trans.R.Soc.B 370: 21 Abr., 2016. Disponivel em: http://rstb.royalsocietypublishing.org Acesso em: 08 Dez. 2016.

PAGEL, Mark. Human language as a culturally transmitted replicator. NATURE REVIEWS GENETICS, V. 10, Jun. p. 405-415, 2009.

STERELNY, Kim. Memes Revisited . Brit. J. Phil. Sci. 57 (2006), 145-165. Disponível em: http://rstb.royalsocietypublishing.org Acesso em: 10 Nov. 2016.

STUART-FOX, Martin. Evolutionary Theory of History. History and Theory, Volume 38, Issue 4: 33-51, Dez. 1999.

TOMASELLO, Michael; TENNIE, Claudio; CALL, Joseph. Ratcheting up the ratchet: on the evolution of cumulative. Phil. Trans. R. Soc. B, 364, p. 2405 - 2415, 2009. 